\title{
sciendo
}

DOI: 10.2478/orga-2019-0017

\section{Analysis of Internally Generated Goodwill Indicators: A Case Study of the Slovak Republic}

\author{
Ivana PODHORSKA ${ }^{1}$, Lubica GAJANOVA ${ }^{1}$, Jana KLIESTIKOVA ${ }^{1}$ and \\ Gheorghe H. POPESCU²
}

\author{
${ }^{1}$ University of Zilina, The Faculty of Operation and Economics of Transport and Communications, Department of \\ Economics, Univerzitna 1, 01026 Zilina, Slovak Republic, ivana.podhorska@fpedas.uniza.sk, \\ lubica.gajanova@fpedas.uniza.sk, jana.kliestikova@fpedas.uniza.sk. \\ 2Dimitrie Cantemir Christian University, Bucharest, Romania, popescu_ucdc@yahoo.com
}

\begin{abstract}
Background and purpose: Knowing key indicators of goodwill value can contribute to its effective management and growth of the market value of the enterprise. The purpose of this research is to identify individual goodwill indicators. The paper aim is to obtain potential indicators of enterprise goodwill under the conditions of the Slovak Republic. Design/Methodology/Approach: Paper data included 11,483 financial statements of Slovak enterprises in 2017. The value of residual enterprise income represents the value of goodwill. Input data for the identification of goodwill indicators represented 15 financial-economic variables. Outliers in data were searched and removed through an interquartile range. Multicollinearity among input variables, by the coefficient of determination and variance inflation factor, was also analysed. A statistically significant correlation between goodwill and its potential indicator were tested by the significance test of the Pearson correlation coefficient and correlation matrixes.

Results: Research results reveal the existence of a statistically significant correlation between goodwill and 8 input variables, which represent its potential vital indicators.

Conclusion: Paper findings bring new possibilities for goodwill management, which may create an essential competitive advantage of a company. For the scientific community, the findings represent sources of potential goodwill indicators which can be used for the creation of the new model of goodwill valuation in future research.
\end{abstract}

Keywords: Goodwill; Residual income; Key indicators; Correlation

\section{Introduction}

In general, goodwill has often defined as the enterprise reputation, image, right name, prestige, as well as the brand. It is reflected in the relationship between enterprise and other market participants and enterprise perception in the eyes of its customers. Traditionally, we distinguish between two types of goodwill: namely, purchased goodwill and internally generated goodwill. Purchased goodwill is the difference between the value paid for an enterprise as a going concern and the sum of its assets less the sum of its liabilities, each item of which has been separately identified and valued. It appears as a result of mergers and acquisition and its valuation is regulated by IFRS 3 Business Combination. On the other hand, internally generated goodwill is an asset that can significantly contribute to the business success of companies. Its value may be very high, although it is not visible directly in the financial statements. It can be defined as the potential intangible asset of the enterprise and it is expected that future economic future benefits, attributable to the asset, will flow to the enterprise. Its accounting is regulated by the International Accounting Standard 38 Intangible Assets (IAS 38). Ac-

Received: July 7, 2019; revised: November 6, 2019; accepted: November 15, 2019 
cording to IAS 38 internally generated goodwill cannot be recognized as an asset because it does not represent enterprise's resource that meet all listed criteria: (i) identification; (ii) control; (iii) measurable (Stefanovic et al., 2014). Internally generated goodwill will be the main subject of interest in the paper, hereinafter referred as to "Goodwill". Enterprise with goodwill has more satisfied and loyal customers and employees. Its suppliers are more willing to cooperate, as well as its investors are more tolerant and willing to finance business development. "Goodwill has created for years, but it can be destroyed almost every day." (Casson, 1997).

Goodwill, as an economic phenomenon has attracted the attention of economic experts since the nineteenth century. During years have been created various methods for its valuation and quantification. This study primary works with the residual income valuation method. The issue enterprise goodwill is an interdisciplinary question; indicators of goodwill creation can be found in financial management, economics, law, marketing, sociologist, etc. However, knowledge and understanding of enterprise goodwill indicators and valuation is still a managerial challenge. Their identification can lead to its effective creation and management, and ultimately to be a powerful tool in the competitive struggle.

The topicality of this issue confirms the number of papers published in the database Web of Science (more than 70 papers about goodwill valuation, measurement) or database Scopus (more than 50 papers). Importance of this issue proves an amount of authors, e.g. Lord Eldon (1842), Leake (1921), Nelson (1953), Hughes (1982), Feltham and Ohlson (1995), Lonergan (1995), Canibano et al. (2000), Fernandez (2002), Curtis and Fargher (2003), Begley et al. (2006), Bean (2011), Herz (2011). Recency of this issue proves and amount of current papers, e.g. Kariuki et al. (2013), Reilly (2015), Tsai (2012), Kimbro and Xu (2016), Kliestik et al. (2018), Sadaf et al. (2019).

The body of paper consist of (i) literature review of enterprise goodwill development; (ii) methodology; (iii) results; and (iv) discussion, including limitations and extensions for future research. Research on possible indicators of enterprise goodwill, their analysis, selection, quantification, etc. represents a complicated and time-consuming process that requires a carefully compiled data sample.

\section{Literature review}

The enterprise goodwill has represented as an essential and interdisciplinary topic for corporate finance in the economic community since the 19th century. Over the years have been created several approaches to the definition of enterprise goodwill. The first approach was "law direction" - in the beginning, goodwill described as a part of lawsuits. The second approach was "economic direction". This approach prevails to the present day. Goodwill has attracted several scientists from various disciplines over the years. The review of selected goodwill definitions captured in Table 1.

Table 1: Summary of selected previous research - goodwill definition

\begin{tabular}{|l|c|l|}
\hline \multicolumn{1}{|c|}{ Author } & Year & \multicolumn{1}{c|}{ Definition } \\
\hline Lord Eldon & 1842 & $\begin{array}{l}\text { The good-will, which has been the subject of sale is nothing more than the probability that the } \\
\text { old customers will resort to the old place. }\end{array}$ \\
\hline Lord Macnaghten & 1845 & $\begin{array}{l}\text { Goodwill is composed of a variety of elements. It differs in its composition in different trades } \\
\text { and different businesses in the same trade. One element may preponderate here and another } \\
\text { element here. }\end{array}$ \\
\hline Lord Macnaughton & 1901 & $\begin{array}{l}\text { What is goodwill? It is a thing straightforward to describe, challenging to define. Goodwill is } \\
\text { the benefit and advantage of the proper name, reputation, and connection of a business. }\end{array}$ \\
\hline Lord Justice Lindely & 1901 & $\begin{array}{l}\text { Goodwill, as a part of company assets, does not make sense. It only makes sense if it connected } \\
\text { with some business. It means term goodwill includes everything that adds value to enterprise } \\
\text { from various reasons, e.g. place, reputation, image, relationships, customer's loyalty, etc. }\end{array}$ \\
\hline Paton & 1922 & $\begin{array}{l}\text { Goodwill represents intangible assets, and its value represents the difference between the total } \\
\text { value of the enterprise and the sum of every physical enterprise assets. Goodwill represents the } \\
\text { enterprise ability to create abnormal earnings. }\end{array}$ \\
\hline Yang & 1927 & $\begin{array}{l}\text { Goodwill represents the current value of expected future earnings of an established enterprise, } \\
\text { which the new company would not achieve. }\end{array}$ \\
\hline Catlett et al. & 1968 & Goodwill is abnormal earnings capacity. \\
\hline Tearney & 1973 & Goodwill is an item which includes many other intangible items. \\
\hline
\end{tabular}


Table 1: Summary of selected previous research-goodwill definition (continued)

\begin{tabular}{|l|l|l|}
\hline Hughes & 1982 & $\begin{array}{l}\text { The debate around goodwill was possible because even though the origin of goodwill can be } \\
\text { determined, its nature will always be prone to interpretation. }\end{array}$ \\
\hline Peasnell & 1982 & Goodwill is the amount of value that a good corporate reputation adds to its overall value. \\
\hline $\begin{array}{l}\text { Shenkar and Yucht- } \\
\text { manYaar }\end{array}$ & 1997 & $\begin{array}{l}\text { Reputation, image, prestige, and goodwill are concepts used by different disciplines, e.g., eco- } \\
\text { nomics, marketing, sociology, and accounting, to denote the general standing of organizations } \\
\text { among their counterparts. }\end{array}$ \\
\hline Arnold & 1992 & Goodwill is a problem that will not go away. \\
\hline Casson & 1977 & $\begin{array}{l}\text { Goodwill is like a health - unappreciated wealth that everyone wants to have, but few are } \\
\text { willing to make efforts to preserve it. }\end{array}$ \\
\hline Maly & 2002 & $\begin{array}{l}\text { Goodwill represents the excellent reputation of enterprise for its business partners, financial } \\
\text { institutions, the public and customers in domestic country and also in abroad. }\end{array}$ \\
\hline Zelenka & 2006 & Goodwill is an enterprise reputation. \\
\hline Bloom & 2008 & $\begin{array}{l}\text { There is a great controversy in detecting what is goodwill and what is it composed of because } \\
\text { it is used interdisciplinary. }\end{array}$ \\
\hline Goodman & 2016 & None of us can buy goodwill; we must earn it. \\
\hline Charlynne et al. & 2018 & Goodwill is an interdisciplinary question and intangible assets. \\
\hline
\end{tabular}

The issue of enterprise goodwill was also discussed by the authors Vojtovic (2016); Slavik and Zagorsek (2016); Cygler and Sroka (2017); Siekelova (2017); Dvorsky et al. (2017); Kliestik et al. (2018); Sadaf et al. (2019).

Generally, one problem is the definition and content of the term goodwill itself. On the other hand, in practice exists another problem - quantification of its value. Economic experts from all the world have suggested several possibilities of its quantification. These methods include for example the super-profits theory of goodwill described by Leake (1921); the momentum theory of goodwill described by Nelson (1953); components goodwill analyse described by Lonergan (1995) or residual income valuation described by Preinreich (1936).

This study works with the application of the residual income valuation method to evaluate enterprise goodwill. Preinreich described residual income valuation theory in 1936. Later, renewed attention paid to the residual income, as to an economic profit (Nauroth, 2002; Emerling and Wojcik-Jurkiewicz, 2018) or abnormal earnings (Ohlson, 1995). Based on their idea of residual income was created Residual Income Valuation Models. One of them is the model, which was created by Feltham and Ohlson in 1995. In their model, they supposed that the value of the enterprise is formed by the sum of the book value of the enterprise equity and the present value of expected future residual income. It is residual income, which creates the difference between the market value of the enterprise and the book value of the enterprise. Residual income represents the source of difference between the market value of the enterprise and the book value of the enterprise. Subsequently, the value of residual income should equal to the enterprise goodwill.

\section{Hypothesis}

The purpose of this research is to identify individual goodwill indicators. The paper aim is to obtain potential indicators of enterprise goodwill under the conditions of the Slovak Republic. Fulfilling the prerequisite and objective of this article also entails the formulation of the primary hypothesis:

H: There is not a significant relationship between individual indicator and goodwill.

This hypothesis is tested for all of the individual potential goodwill indicators which are chosen for this research and purpose. In total is it 15 hypotheses.

\section{Methodology}

\subsection{Enterprise goodwill valuation}

Residual income represents income, which enterprise created over the level of the income required by its owners. Determination of required income for owners is necessary. According to the residual income theory by Feltham and Ohlson (1995), the required income for owners is equal to the cost of equity. Disadvantages are special barriers in the process of their quantification, especially under the condition of the inefficient capital market, as well as in Slovak Republic. Quantification of residual income has the following form: 
$R I=N I-$ equity charge

Where

RI

$\mathrm{NI}$

residual income

net income

The determination of equity charge represents the key calculation of the residual income. Due to the fact, equity charge is the product of the book value of equity and its cost. This fact depicted in the following equation:

equity charge $=r_{E}^{*} B V_{E}$

Where

$r_{E}$

cost of equity

BVE

book value of equity

The cost of equity is calculated by CAMP with country risk premium (CRP). According to Damodaran (http:// pages.stern.nyu.edu/ adamodar/):

$r_{e}=r_{f U S A}+\beta^{*} E R P_{U S A}+C R P$

Where

$\mathrm{r}_{\text {fUSA }} \quad$ risk-free rate; yield of bonds that calculate the risk premium of the market, i.e. the yield of US 10-year government bonds according to Damodaran website

ERP equity risk premium $\left(\mathrm{R}_{\mathrm{m}}-\mathrm{r}_{\mathrm{f}}\right) ; \mathrm{R}_{\mathrm{m}}$ represents S\&P500 according to Damodaran website

$\beta \quad$ beta for emerging markets according to Damodaran website

CRP risk premium for other markets according to Damodaran website.

\subsection{Data and sample}

The sample for the identification of significant indicators of enterprise goodwill creation consisted of financial statements of Slovak enterprises in 2017. These data obtained from the Amadeus database system ${ }^{1}$ - a comprehensive European database on public and private companies; available at https://amadeus.bvdinfo.com/. Relevant sample for our research of enterprise goodwill consisted of 11,483 financial statements of Slovak enterprises in 2017. Sample creation contained 2 conditions: (i) limited companies; (ii) domestic ownership. The representation of the individual Slovak regions in the sample uninformed - approximately $10 \%$ for each region. The sample also diversified to companies with various SK NACE classification. Thanks to these conditions were created robust data sample which can provide general results (for all regions and all sectors). Working data included 11,483 financial statements of Slovak enterprises in 2017. Input data for the identification of goodwill indicators represented 15 financial-economic variables.

\subsection{Data analysis}

Paper main aim was to obtain potential indicators of enterprise goodwill under the conditions of the Slovak Republic. For their identification were used several methods in the section of the data analysis. The detection of outliers was done by interquartile range. The detection of multicollinearity between variables (potential indicators of enterprise goodwill) was tested by the coefficient of determination and variance inflation factor. Finally, the detection of correlation between residual income and potential indicators of its creation was tested by correlation matrixes for all variables and the test of significance of the Pearson correlation coefficient. All statistics test was tested at the significance level $\alpha=0.05$.

Discriminant validity was assessed by using two methods: First,(Fornell \& Larcker, 1981) method. He suggested that to support for discriminant validity if the square root of the AVE for a latent construct is greater than the correlation values among all the latent variables. Table (5) shows that the square root of the AVE values of all the constructs is greater than the inter-construct correlations which supports the discriminant validity of the constructs. Second, (Hair et al., 2010) he suggests if AVE for a latent construct is larger than the maximum shared variance with other latent constructs that indicates discriminant validity can be maintained Thus, the measurement model indicates a good construct validity and desirable psychometric properties.

${ }^{1}$ Amadeus is a database of the comparable financial and business information on Europe's largest 520,000 public and private companies by total assets. 43 countries are covered. Amadeus is published by Bureau van Dijk/Moody's Analytics. Amadeus provides standardised annual accounts (consolidated and unconsolidated), financial ratios, sectoral activities and ownership data. The database is suitable for research on competitiveness, economic integration, applied microeconomics, business cycles, economic geography and corporate finance. Amadeus is updated weekly, providing standardised annual accounts with up to ten years archive. EUI users can access Amadeus campus-wide via this Catalogue record (two simultaneous users). There is no off-campus access. 


\section{Results}

\subsection{Goodwill indicators}

Potential indicators of enterprise goodwill creation (obtained from the robust analysis of domestic and foreign scientific literature dealing with the value of enterprise and goodwill. These indicators are grouped in the three categories: (i) financial-economic analysis; (ii) analysis of financial statements; and (iii) other. Category (i) includes financial ratios from enterprise liquidity, profitability, activity and indebtedness. These indicators represent the level of enterprise financial health. The causality between enterprise financial ratios and goodwill was examined by authors Curtis \& Fargher, 2003 examined the causality between enterprise financial ratios and goodwill; Begley et al., 2006; Maleki et al., 2010; Jakubec et al., 2011; Sponte, 2018. Category (ii) includes indicators from enterprise financial statements; they focused on intangible assets and specific cost, e.g. marketing cost. The causality between enterprise status indicators and goodwill was separately examined and recommended by authors Courtis, 1983; Kohlbeck \& Warfield, 2002; Siekelova, 2017; Nica et al., 2017; Olah et al., 2019. Last category (iii) includes other indicators. Finally, the following 15 variables were selected into this paper (Table 2); the last column represents their quantification.

Table 2: Potential indicators of enterprise goodwill

\begin{tabular}{|c|c|c|}
\hline Variable & Mark & Calculation \\
\hline cash ratio & $\mathrm{CR}$ & (cash + cash equivalents)/current liabilities \\
\hline debt-equity ratio & DER & equity/total liabilities \\
\hline $\begin{array}{l}\text { the turnover ratio from short- } \\
\text { term payables }\end{array}$ & TUR & (short-term payables from business/costs) $* 365$ \\
\hline return on equity & ROE & earnings after taxes/equity \\
\hline net income previous year & NIP & earnings after taxes from the previous year from the balance sheet \\
\hline retained earnings prior years & RE & retained earnings from previous year from the balance sheet \\
\hline valuable rights & VR & valuable rights from the balance sheet \\
\hline research and development costs* & $\mathrm{R} \& \mathrm{D}$ & research and development costs from the balance sheet \\
\hline marketing costs ${ }^{*}$ & $\mathrm{MC}$ & $(15 \% *$ service costs from the income statement $)$ \\
\hline staff training costs ${ }^{*}$ & $\mathrm{SC}$ & $(10 \% *$ service costs from the income statement $)$ \\
\hline investments into the plant ${ }^{*}$ & INP & (annual change from the balance sheet (brutto)) \\
\hline investments into the equipment ${ }^{*}$ & INE & (annual change from the balance sheet (brutto)) \\
\hline $\begin{array}{l}\text { investments into the property } \\
\text { (buildings) }^{*}\end{array}$ & INB & (annual change from the balance sheet (brutto)) \\
\hline age of enterprise & $\mathrm{AE}$ & time since the enterprise establishment to 2015 \\
\hline market share & MS & $\begin{array}{l}\text { sales from operating activities/sales from operating activities } \\
\text { in the industry }\end{array}$ \\
\hline
\end{tabular}

*Note: necessary to take into account the time effect of the variable to the residual income (goodwill), e.g. for marketing costs assumed the effect of two years and so on.

**Note: for or all variables were set up recommended values - what are the values the indicators of residual income (goodwill) should achieve to be considered as potential indicators of its production. Most variables should be higher than zero, except cash ratio $(<0.2-0.8>)$, debt-equity ratio $(\geq 0.04)$ and turnover ratio from short-term payables $(\leq 60)$, in accordance with (Kohlbeck \& Warfield, 2002; Podolna, 2008; Bean, 2011; Rajnoha \& Lesnikova, 2016; Da Silva et al., 2015; Szkutnik \& Szkutnik, 2018; Valaskova et al., 2018; Fanelli \& Ryden, 2018). 


\subsection{Data analysis}

For the identification of potential indicators of enterprise goodwill we used several methods presented in the section of the data analysis. The detection of outliers was done by interquartile range. The detection of multicollinearity between variables (potential indicators of enterprise goodwill) was tested by the coefficient of determination and variance inflation factor. Finally, the detection of correlation between residual income and potential indicators of its creation was tested by correlation matrixes for all variables and the test of significance of the Pearson correlation coefficient. Table 3 (Appendix) shows the value of descriptive statistics in data.

\section{Outliers detection and missing data}

Detection of outliers contained searching for outliers, missing values and economic consequences. Enterprises with a negative residual income had to be removed from the database as well as enterprises with missing values and finally, outliers of individual model indicators. Table 4 (Appendix) shows the number of removed enterprises from further research. Overall, 2,478 outliers and missing data removed from the database. Finally, the database for searching for potential indicators of enterprise goodwill contained 9,005 enterprises $(11,483$ original data $-2,478$ outliers and missing data).

\section{Multicollinearity detection}

Tables 5 and 6 (Appendix) show the results of the test of multicollinearity between all potential goodwill indicators. Table 5 shows the correlation matrix of all goodwill indicators. Finally, the values of the coefficient of determination $\mathrm{R}^{2}$ and variance inflation factor VIF were calculated based on the results of correlation and inverse matrixes (Table 6).

The multicollinearity test showed that absolute multicollinearity is found between the $\mathrm{MC}$ and $\mathrm{SC}$ variables (the value of $\mathrm{R}^{2}$ is equal to 1 , and the value of VIF approaches infinity). As in the methodology, the simplest solution is removing one of the two variables between which the dependency exists. In this research was removed variable SC - staff training costs. It was removed because it can be assumed the higher correlation between enterprise goodwill and marketing costs. Subsequently, the test of multicollinearity was repeated. The results of the retest are shown in Tables 7 and 8 (Appendix). The second test of multicollinearity did not show the existence of multicollinearity among any input variables.

\section{Detection of correlation}

Based on the results of the correlation matrixes (Appendix, Table 9), it may be stated the existence of direct linear dependence between residual income and all potential indicators of its creation. However, the tightness of this dependency is diverse. There is a weak linear relationship between the variable residual income and variables $C R$, DER, TUR, VR, MC, INP, INB, EA and MS. There is a medium linear relationship between the variable residual income and variables ROE, NIP, RE and INE. Based on the results of correlation matrixes, the existence of a strong relationship of none of the input variables has not been confirmed.

Table 10 (Appendix) shows a summary results of the statistical testing of significance of correlation coefficient for all input variables. This test shows whether there is or there is not a statistically significant relationship between variables, which means between residual income and potential indicators of its creation.

Based on the data shown in the Table 10 can be noted that the value of test statistic is lower than the critical value for CR, DER, TUR, INP and AE. In accordance with the level significance $\alpha=0.05$ the null hypothesis was accepted, and there was not the dependence between them and residual income. For variables ROE, NIP, RE, VR, MC, INB, INE and MS was the value of test statistic higher than the critical value, at the significance level $\alpha=0.05$ the null hypothesis was rejected, indicating there was the statistical significant dependence between them and residual income.

These facts and results of test statistics create a basis for future research in the area of the creation of an econometric model of enterprise goodwill quantification. Quantification of the dependent variable and independent variables, detection of outliers and multicollinearity test are basic assumptions for regression analysis, among others. Especially, for future research and creation of an econometric model of enterprise goodwill quantification regression analysis can be used. The advantage of correlation matrixes results for future econometric model is confirmation of existence of potential sources of enterprise goodwill creation, represent by medium linear relationship between individual indicators and residual income. On the other hand, the disadvantage of correlation analysis is the number indicators with weak linear relationship between them and residual income. However, we can assume that these variables will be removed by regression analysis itself. For future econometric model and regression analysis multicollinearity analysis is very important. An existence of milticollinearity between input variables could lead to incorrect results and misinterpretation. Our research highlights potential existence of multicollinearity between variables as marketing costs, staff training costs or maybe $R \& D$ costs, it depends on basis of their calculation. In this case is necessary to consider the contribution of individual indicators to overall value of enterprise goodwill and accept suitable decision about their future role in econometric model and goodwill creation as a whole. 


\section{Discussion}

Paper main aim was to obtain potential indicators of enterprise goodwill under the conditions of the Slovak Republic. Our research demonstrated the existence of a significant relationship between enterprise goodwill and some ratios which can be considered as its indicators. Various authors separately examined the causality between enterprise goodwill and financial ratios, status indicators and another ratio.

Paper research showed as statistical significant goodwill indicators: return on equity, net income previous years, retained earnings prior years, valuable rights, marketing costs, investments into the property, investments into the equipment and market share. These findings are partly consistent with the conclusion of Da Silva et al. (2015) where researched the linear correlation between the variables such as assets, equity, net income, income before a financial transaction, the consolidated profit and loss and indices such as ROE. Similarly, Tsai et al. (2012) consider investing, advertising, research and development as significant indicators of enterprise goodwill. Our research confirmed the existence of significant causality between goodwill and advertising/marketing costs.

Our research brought the space for research extension. Future research may be focused on the application of the multiple linear regression analysis to these data. Where residual income will represent the dependent variable and indicators/potential sources of its value will represent independent variables. This test could bring the new model for goodwill valuation and prediction.

This research has various limitations. It is crucial to highlight the impact of various possibilities to calculate individual variables on the final calculations. These possibilities represent limitations as well as possible extensions of this research. The calculation of the cost of equity has a significant impact on the calculation of the value of residual income according to the Feltham-Ohlson model (1995). The cost of equity was calculated according to the capital asset pricing model (similarly to Da et al., 2012 or Feltham-Ohlson, 1995). Methods for quantification of the cost of equity represents another limitation of this research. The presented study tried to determine potential indicators of enterprise goodwill in the Slovak conditions. Therefore, the main limitations were in the selected goodwill indicators used as independent variables. The selection of other variables could have led to different results, which can be a subject of analysis in future studies. Prerequisite values of input variables give another significant limitation. These were specified according to the provided literature review and respecting specifics of the Slovak environment, but not so strict determination of values of indicators can provide different results. The last limitation is represented by used data. The results cannot be generalized yet because of used data only from the Slovak Republic.
The findings presented in this study have opened a space for a more in-depth insight into the dimensions of the goodwill evaluation in the Slovak enterprises that absent in the scientific studies not only in specific conditions of Slovakia but also worldwide, particularly for its methodological difficulty and data limitations. The issue of enterprise goodwill is an interdisciplinary task and managerial challenge. Searching for potential indicators of goodwill can lead to its effective creation and management, and ultimately to be a powerful tool in the competitive struggle. So there was a need to found out the possible indicators of its creation in Slovak enterprises through which can help enterprise management increase its value.

\section{Conclusion}

The market economy brings a situation where the market value of the enterprise is higher than the book value of the enterprise. This difference is known as enterprise goodwill. The value of enterprise goodwill adds value to the enterprise in the market. The management of critical indicators of enterprise goodwill still represents a managerial challenge. Although the enterprise goodwill has represented as an essential and interdisciplinary topic for corporate finance in the economic community since the 19th century, it is still a relatively unknown area. Knowing goodwill value key indicators can contribute to its effective management and growth of the market value of the enterprise.

Research theoretical findings bring a review of the scientific literature development for issue of goodwill. Subsequently, the possibility of goodwill quantification focused on residual income valuation.

Besides the theoretical implications, this study provides practical implications. The purpose of this research was to identify individual goodwill indicators. The paper aim was to obtain potential indicators of enterprise goodwill under the conditions of the Slovak Republic. Tested hypothesis: There is a statistically significant relationship between indicator and goodwill, confirmed the existence of a statistically significant correlation between goodwill and 8 input variables, which represent its potential key indicators. Research aim and purpose have fulfilled.

Paper findings bring new possibilities for its management and may create an important competitive advantage. For the scientific community, the findings represent sources of potential goodwill indicators which can be used for the creation of the new model of goodwill valuation in future research. Paper research brought the space for research extension. Future research may be focused on the application of the multiple linear regression analysis to these data. Where residual income will represent the dependent variable and indicators/potential sources of its value will represent independent variables. This test could bring the new model for goodwill valuation and prediction. 


\section{Acknowledgement}

The research leading to these results has received funding from the project titled "Integrated model of management support for building and managing the brand value in the specific conditions of the Slovak Republic" in the frame of the program of Slovak Research and Development Agency under the grant agreement number APVV-15-0505.

\section{Literature}

Arnold, J. (1992). Goodwill: A Problem that will not Go Away. Trade Publication Accountancy. 109(1186), 35.

Bean, A. (2011). Hunting Goodwill: Personal Goodwill as Property in Corporate Acquisitions. Journal of Corporate Accounting \& Finance, 23(2), 55-61. https://doi.org/10.1002/jcaf.21737

Begley, J., Chabmerlman, S. L. \& Li, Y. H. (2006). Modeling Goodwill for Banks: A Residual Income Approach with Empirical Tests. Contemporary Accounting Research. 23, 31-68.

https://doi.org/10.1506/DVWU-BWTW-B018-LMTA

Bloom, M. (2008). Double Accounting for Goodwill: A Problem Redefined. New York: Taylor \& Francis Group.

Catlett, G. R. \& Olson, N. O. (1968). Accounting Research Study NO. 10. Aicpa, New York.

Canibano,L.etal.(2000).Accounting forIntangibles:ALiterature Review.JournalofAccountingLiterature, 102-130.

Charlynne, B., Machova, V., Kovacova, M., \& Valaskova, K. (2018). The Power of Human-Machine Collaboration: Artificial Intelligence, Business $\mathrm{Au}-$ tomation, and the Smart Economy. Economics, Management, and Financial Markets, 13(4), 51-56.

Courtis, J.K. (1983). Business Goodwill: Conceptual Clarification Via Accounting, Legal and Etymological Perspectives. The Accounting Historians Journal, 10, 1-38. https://doi.org/10.2308/0148-4184.10.2.1

Curtis, A. \& Fargher, N.L. (2003). A Comparison of Residual Income and Comparable Firm Valuation of Initial Public Offerings. SSRN Electronic Journal.

Cygler, J., \& Sroka, W. (2017). Coopetition Disadvantages: The Case of the High Tech Companies. Inzinerine Ekonomika - Engineering Economics, 28(5), 494-504. https://doi.org/10.5755/j01.ee.28.5.16421

Da, Z., Guo, R. J. \& Jagannathan, R. (2012). CAPM for Estimating the Cost of Equity Capital: Interpreting the Empirical Evidence. Journal of Financial Economics, vol. 103, pp. 204220. https://doi.org/10.1016/j.jfineco.2011.08.011.

Damodaran (2017) website. Available at http://pages.stern.nyu.edu/ adamodar/.

Da Silva, I.D. et al. (2015). Intangible Assets: Relationship with Tangible Assets and Financial Ratios. Revista Gestao Organizacional, 8, 26-40.

Dvorsky, J., Sopkova, G., \& Janoskova, M. (2017). Evaluation of the Social Environment and Ac- cess to Financial Resources for Business: Case Study of the Czech and Slovak Republic. Ekonomicko-manazerske Spektrum, 11(1), 6273. https://doi.org/10.26552/ems.2017.1.62-73.

Emerling, I., \& Wojcik-Jurkiewicz, M. (2018). The Risk Associated with the Replacement of Traditional Budget with Performance Budgeting in the Public Finance Sector Management. Ekonomicko-manazerske Spektrum, 12(1), 55-63. https://doi.org/10.26552/ems.2018.1.55-63.

Fanelli, V., \& Ryden, A.K. (2018). Pricing a Swing Contract in a Gas Sale Company. Economics, Management, and Financial Markets, 13(2), 4055. https://doi.org/10.22381/emfm13220183.

Feltham, G.A., \& Ohlson, J.A. (1995). Valuation and Clean Surplus Accounting for Operating and Financial Activities. Contemporary Accounting Research, 11, 689-731. https://doi.org/10.1111/j.1911-3846.1995.tb00462.x

Fernandez,P.(2002). ThreeResidualIncomeValuationMethods and Discounted Cash Flow Valuation. SSRN Electronic Journal. https://doi.org/10.2139/ssrn.296945

Goodman, T. (2016). Forbes Book of Quotations: 10,000 Thoughts on the business of life. New York: Black Dog \& Leventhal.

Herz, R.H. et al. (2001). Equity Valuation Models and Measuring Goodwill Impairment. Accounting Horizons, 15, 161-170. https://doi.org/10.2308/acch.2001.15.2.161

Hughes, H.P. (1982). Goodwill in Accounting: A History of the Issue and Problems. Atlanta: Georgia State University, [Research Monograph]. IFRS 3 Business combination and IAS 38 Intangible assets. Ivanova, E., \& Cepel, M. (2018). The Impact of Innovation Performance on the Competitiveness of the Visegrad 4 Countries. Journal of Competitiveness, 10(1), 54-72. https://doi.org/10.22381/emfm13420184

Jakubec, M., Kardos, P., \& Kubica, M. (2011). Management of the Company Value, Bratislava: Kartprint.

Kariuki, B.W. \& Qyugi, L.A. (2013). Testing the Residual Income Valuation Model in a Nascent Stock Market: The case of Nairobi Securities Exchange, International Journal of Business and Social Science, 4, pp. 69-77.

Kimbro, M.B., \& Xu, D. (2016). The Accounting Treatment of Goodwill, Idiosyncratic Risk, and Market Pricing. Journal of Accounting Auditing and Finance, 31, 365-387. https://doi.org/10.1177/0148558x16632414

Kohlbec, M. \& Warfield, T. (2002). The Role of Unrecorded Intangible Assets in Residual Income Valuation: The Case of Banks. SSRN Electronic Journal. https://doi.org/10.2139/ssrn.296387

Kovacova, M., \& Kliestik, T. (2017). Logit and Probit Application for the Prediction of Bankruptcy in Slovak Companies. Equilibrium. Quarterly Journal of Economics and Economic Policy, 12(4), 775-791. https://doi.org/10.24136/eq.v12i4.40

Kovacova, M., Kliestik T., Kubala P., Valaskova K., Radisic M., \& Borocki J. (2018). Bankruptcy Models: Verifying Their Validity As a Predictor of Corporate 
Failure. Polish Journal of Management Studies, 18(1), 167-179. https://doi.org/10.17512/pjms.2018.18.1.13

Kliestik, T, Kovacova, M., Podhorska, I., \& Kliestikova, J. (2018). Searching for Key Sources of Goodwill Creation as New Global Managerial Challenge. Polish Journal of Management Studies, 17(1), 144154. $\quad$ https://doi.org/10.17512/pjms.2018.17.1.12

Leake, P.D. (1921). Commercial Goodwill. Its History, Value and Treatment in Accounts, London: Sir Isaac Pitman and Sons, Ltd. Lonergan, W. (1995). Goodwill and Bad Ideas; Fact and Fiction in the Amortisation Debate. Jassa, 4, 2-7. Maly, J. (2002). Intangible Goods Trade, Praha: C.H. Beck. Maleki, M. A. et al. (2010). Value Relevance of Accounting-based Valuation Models: The Accuracy of the Abnormal Earnings Growth and Residual Income Model: Evidence from Europe. University of Amsterdam.

Nelson, H.R. (1953). The Momentum Theory of Goodwill. The Accounting Review, 28, 491-499.

Nica, E., Comanescu, M., \& Manole, C. (2017). Digital Reputation and Economic Trust in the Knowledge Labor Market. Journal of Self-Governance and Management Economics, 5(3), 83-88. https://doi.org/10.22381/jsme5320174

Ohlson, J. (1995). Earnings, Book Values, and Dividends in Equity Valuation, Contemporary Accounting Research. 661-687.

Olah, J., Kovacs, S., Virglerova, Z., Lakner, Z., \& Popp, J. (2019). Analysis and Comparison of Economic and Financial Risk Sources in SMEs of the Visegrad Group and Serbia, Sustainability, 11(7), 1-19. https://doi.org/10.3390/su11071853

Peasnell, K. (1982). Some Formal Connections between Economic Values and Yields and Accounting Numbers. JournalofBusiness FinanceandAccounting, 9,361-381. https://doi.org/10.1111/j.1468-5957.1982.tb01001.x

Podolna, V.V. (2008). Key Aspects of Formation and Development of Positive Goodwill of an Enterprise. Actual Problems of Economics, 87, 128-134.

Preinreich, G. (1936). The Fair Value and Yield of Common Stock. The Accounting Review. 130-140.

Rajnoha, R., \& Lesnikova, P. (2016). Strategic Performance Management System and Corporate Sustainability Concept - Specific Parameters in Slovak Enterprises. Journal of Competitiveness, 8(3), 107-124. https://doi.org/10.7441/joc.2016.03.07

Reilly, R.F. (2015) „Goodwill Valuation Approaches, Methods, and Procedures“. American Bankruptcy Insitute Journal, Alexandria. 34, 10-24.

Sadaf, R., Olah, J., Popp, J., \& Mate, D. (2019). Institutional Ownership and Simultaneity of Strategic Financial Decisions: An Empirical Analysis in the Case of Pakistan Stock Exchange. E\& MEkonomie a Management,22(1), 172-188. https://doi.org/10.15240/tul/001/2019-1-012

Shenkar, O., \& Yuchtmanyaar,E.(1997). Reputation, Image, Prestige, and Goodwill: An Interdisciplinary Approach to Organizational standing. Human Relations, 50, 13611381. https://doi.org/10.1177/001872679705001102
Siekelova, A. (2017). Using Rating for Credit Risk Measurement. In: 17th Annual Conference on Finance and Accounting. Book Series: Springer Proceedings in Business and Economics, 689-697. https://doi.org/10.1007/978-3-319-49559-0 63

Slavik, S., \& Zagorsek, B. (2016). Relationship Between Business Strategy and Business Model Studied in a Sample of Service Companies. Journal of Competitiveness, 8(4), 72-84. https://doi.org/10.7441/joc.2016.04.05

Sponte, M. (2018). Knowledge Work and Labor Market Performance: An Empirical Analysis. Journal of Self-Governance and Management Economics, 6(2), 113-118. https://doi.org/10.22381/jsme6220184

Stefanovic, D., Petrovic, Z., Milojevic, M., \& Stanic, N. (2014). Internally Generated Goodwill Assessment: Contemporary Times Requirement or Not? Proceedings of the Singidunum University International Scientific Conference Financial Reporting Function of the Corporate Governance, Singidunum University. https://doi.org/10.15308/finiz-2014-81-84

Szkutnik W., \& Szkutnik W. (2018). Socio-economic Convergence in Models of Endogeneous Economic Growth. Ekonomicko-manazerske Spektrum, 12(2), 1-14. https://doi.org/10.26552/ems.2018.2.1-14

Tearney, M.G. (1973). Accounting for Goodwill: A Realistic Approach. Journal of Accountancy, vol. 136, no. 1, pp. 41-45.

Tsai, C. F., Lu, Y. H. \& Yen, D. D. (2012). Determinants of Intangible Assets Value: The Data Mining Approaches. Knowledge-Based Systems, vol. 31, pp. 67-77. https://doi.org/10.1016/j.knosys.2012.02.007

Valaskova, K., Kliestik, T., \& Kovacova, M. (2018). Management of Financial Risks in Slovak Enterprises Using Regression Analysis. Oeconomia Copernicana, 9(1),105-121. https://doi.org/10.24136/oc.2018.006 Vojtovic, S. (2016). The Impact of the Structural Funds on Competitiveness of Small and Medium-Sized Enterprises. Journal of Competitiveness, 8(4), 30-45. https://doi.org/10.7441/joc.2016.04.02

Yang, J. M. (1972). Goodwill and Other Intangible Assets. Ronald Press. New York. Zelenka, V. (2006). Goodwill Principles of Company Reporting. Praha: Ekopress, s.r.o.

Ivana Podhorska (Ph.D.) is a university teacher at the Department of Economics, Faculty of Operation and Economics of Transport and Communications, University of Zilina (Slovak Republic). Research interests: financial management, financial-economic analysis, corporate finance. She has 17 papers in Web of Science. 
Lubica Gajanova (Ph.D.) is a university teacher at the Department of Economics, Faculty of Operation and Economics of Transport and Communications, University of Zilina (Slovak Republic). Research interests: marketing, brand, customer relationship management, corporate social responsibility, accounting. She has 32 papers in Web of Science.

Jana Kliestikova (doc., Ph.D.) is a university teacher at the Department of Economics, Faculty of Operation and Economics of Transport and Communications, University of Zilina (Slovak Republic). Research interests: marketing, brand, customer relationship management, corporate social responsibility, law. She has 37 papers in Web of Science.
Gheorghe H. Popescu is full professor at Dimitrie Cantemir Christian University, Bucharest. He has published more than 50 papers in peer reviewed journals indexed in ISI/Web of Science, Scopus, EconLit, ProQuest and others. He is the editor of three international peer reviewed journals: Economics, Management, and Financial Markets (since 2012), Journal of Self-Governance and Management Economics (since 2013), and American Journal of Medical Research (since 2014). 


\section{Appendix: List of Measurement Items}

Table 3: Descriptive statistic in data

\begin{tabular}{|c|c|c|c|c|c|c|c|c|}
\hline & Mean & StE & Med & StDev & SVar & Range & Min & Max \\
\hline CR & 0.46 & 0.01 & 0.44 & 0.17 & 0.03 & 0.60 & 0.20 & 0.80 \\
\hline DER & 1.88 & 0.52 & 0.77 & 13.21 & 174.5 & 329.9 & 0.04 & 329.9 \\
\hline TUR & 20.33 & 0.67 & 16.78 & 16.97 & 287.8 & 59.64 & 0.00 & 59.64 \\
\hline ROE & 0.42 & 0.03 & 0.30 & 0.73 & 0.54 & 15.11 & 0.00 & 15.11 \\
\hline NIP & $59,448.2$ & $7,656.06$ & $8,822.75$ & $193,078.5$ & $3.73 \mathrm{E}+10$ & $2,226,686.5$ & 0.00 & $2,226,686,5$ \\
\hline RE & $130,151.1$ & $24,385.3$ & 0.00 & $614,975.0$ & $3.78 \mathrm{E}+11$ & $12,099,487$ & 0.00 & $12,099,487$ \\
\hline VR & 748.28 & 420.53 & 0.00 & $10,605.4$ & $1.12 \mathrm{E}+8$ & 186,4 & 0.00 & 186,4 \\
\hline R\&D & 80.48 & 80.48 & 0.00 & $2,029.58$ & $4,119,185.31$ & 51,1 & 0.00 & 51,1 \\
\hline MC & 32,752 & $4,622.7$ & $5,945.5$ & $116,580.3$ & $13,590,983,369$ & $1,957,849.9$ & 0.23 & $1,957,850.1$ \\
\hline SC & 21,834 & $3,081.8$ & $3,963.7$ & $77,720.2$ & $6,040,437,053.1$ & $1,305,233.3$ & 0.15 & $1,305,233.4$ \\
\hline INP & 178.89 & 61.27 & 0.00 & $1,545.09$ & $2,387,315.9$ & $22,393.2$ & 0.00 & $22,393.2$ \\
\hline INE & $10,620,6$ & $1,597.8$ & 0.00 & 40,296 & $1,623,767,606.8$ & 376,923 & 0.00 & 376,923 \\
\hline INB & $86,310.63$ & $12,123.1$ & $13,280.3$ & $305,733.9$ & $93,473,229,651.5$ & $4,908,964,8$ & 0,00 & $4,908,964,8$ \\
\hline AC & 12.47 & 0.19 & 11.00 & 4.87 & 23.72 & 18.00 & 7.00 & 25.00 \\
\hline MS & 0.01 & 0.00 & 0.00 & 0.07 & 0.01 & 1.00 & 0.00 & 1.00 \\
\hline RI & $92,753.1$ & $10,632.5$ & $16,829.2$ & $268,143.6$ & $71,901,037,863.7$ & $3,815,511.4$ & 39.3 & $3,815,550.7$ \\
\hline
\end{tabular}

Source: calculation by authors

Table 4: Detection of outliers and missing data

\begin{tabular}{|c|c|}
\hline Indicator & Outliers and Missing data \\
\hline RI & 1,369 \\
\hline CR & 185 \\
\hline DER & 35 \\
\hline TUR & 66 \\
\hline ROE & 209 \\
\hline NIP & 64 \\
\hline RE & 30 \\
\hline VR & 78 \\
\hline R\&D & 49 \\
\hline MC & 101 \\
\hline SC & 2 \\
\hline INP & 70 \\
\hline INE & 37 \\
\hline INB & 83 \\
\hline AE & 6 \\
\hline MS & 94 \\
\hline Total & 2,478 \\
\hline Adjusted Sample & $\mathbf{9 , 0 0 5}$ \\
\hline & \\
\hline &
\end{tabular}

Source: calculation by authors 


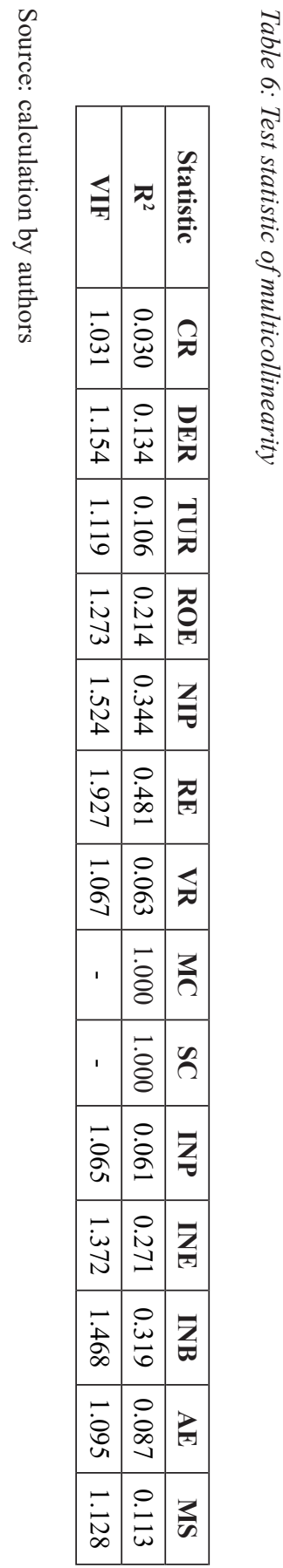

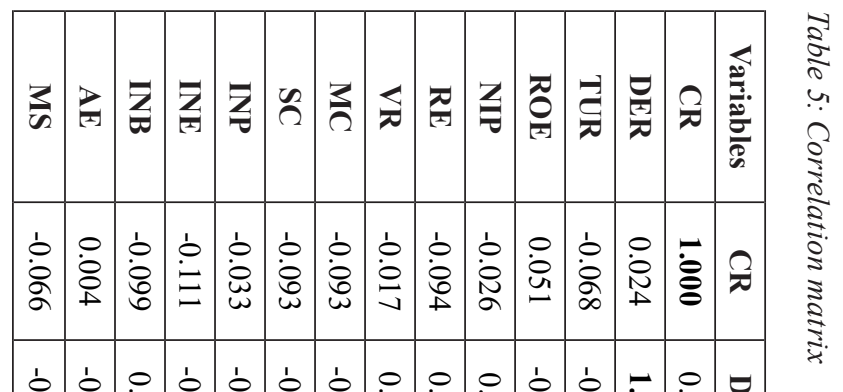

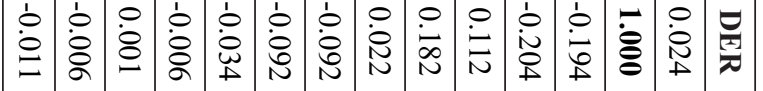

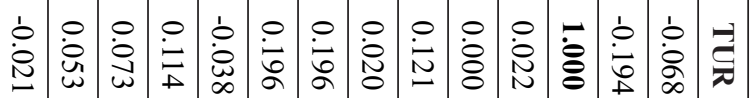

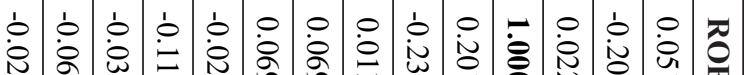

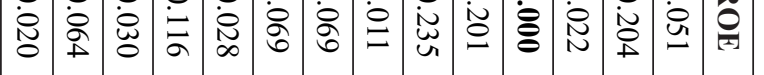

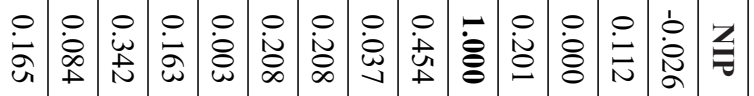

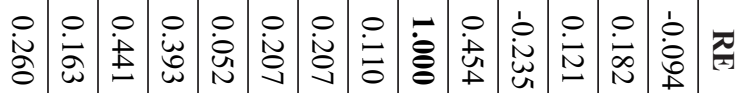

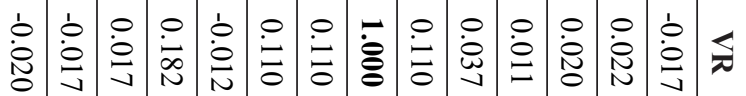

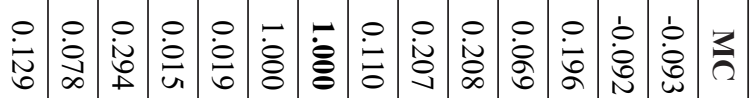

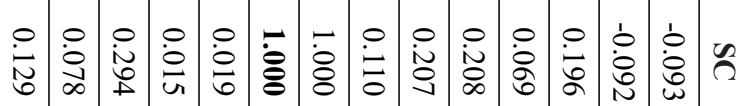

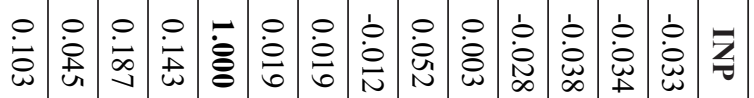

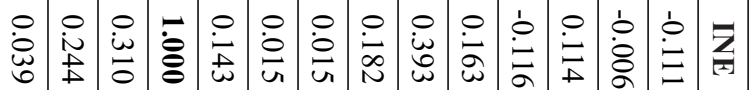

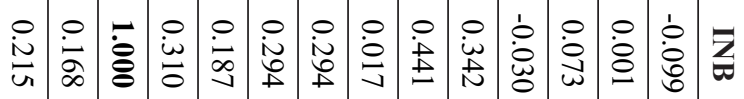

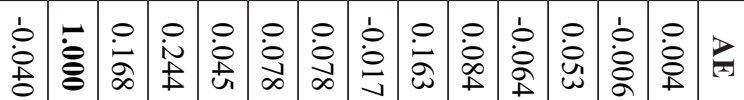

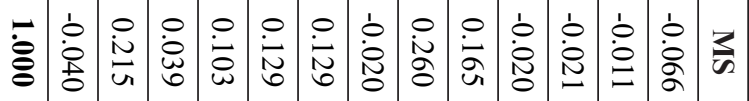




\begin{tabular}{|c|c|c|c|c|c|c|c|c|c|c|c|c|c|}
\hline & $\begin{array}{l}\text { : } \\
0 \\
i\end{array}$ & $\begin{array}{l}\vec{\Xi} \\
\dot{i}\end{array}$ & \begin{tabular}{|l}
$\vec{\delta}$ \\
$\dot{i}$
\end{tabular} & $\mid \begin{array}{l}0 \\
0 \\
0 \\
0 \\
1\end{array}$ & $\frac{n}{0}$ & 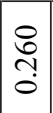 & 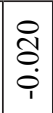 & $\frac{\text { ते }}{0}$ & $\frac{\tilde{o}}{0}$ & 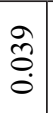 & 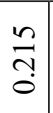 & $\left|\begin{array}{l}0 \\
0 \\
0 \\
0 \\
i\end{array}\right|$ & 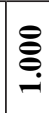 \\
\hline & : & $\begin{array}{l}0 \\
0 \\
0 \\
i\end{array}$ & 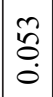 & $\begin{array}{l}\text { to } \\
\text { i. }\end{array}$ & $\begin{array}{l}+ \\
\text { Dे } \\
0 \\
0\end{array}$ & $\frac{6}{0}$ & i. & 立 & 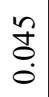 & 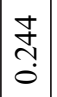 & $\begin{array}{l}\infty \\
\stackrel{0}{0} \\
0\end{array}$ & $\stackrel{\text { ٍ̆ }}{ }$ & 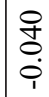 \\
\hline & ì & $\begin{array}{l}\overrightarrow{8} \\
\dot{0}\end{array}$ & $\hat{\tilde{o}}$ & 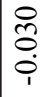 & $\begin{array}{l}\text { fy } \\
\text { dy } \\
0\end{array}$ & 表 & $\stackrel{\bar{\partial}}{\circ}$ & $\begin{array}{l}\text { ¿े } \\
\text { त̂ }\end{array}$ & $\frac{\hat{\infty}}{\stackrel{\infty}{0}}$ & $\frac{0}{m}$ & ڤ్ & $\begin{array}{l}\infty \\
\stackrel{\infty}{0}\end{array}$ & $\frac{\sim}{\tilde{c}}$ \\
\hline & $\begin{array}{l}\exists \\
\vdots \\
i\end{array}$ & & 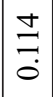 & $\begin{array}{l}\stackrel{0}{7} \\
+\end{array}$ & $\frac{\Omega}{0}$ & $\begin{array}{l}\text { ळे } \\
\text { है }\end{array}$ & $\stackrel{\widetilde{N}}{\stackrel{\infty}{0}}$ & $\stackrel{n}{0}$ & $\frac{f}{\mathcal{f}}$ & 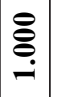 & $\stackrel{\circ}{m}$ & $\begin{array}{l}\underset{J}{J} \\
\text { Ò }\end{array}$ & के \\
\hline & $\begin{array}{l}\tilde{o} \\
\stackrel{0}{i}\end{array}$ & 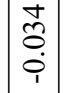 & 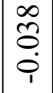 & 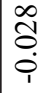 & 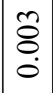 & $\begin{array}{l}\tilde{\delta} \\
\dot{0} \\
0\end{array}$ & 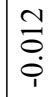 & $\stackrel{\partial}{0}$ & 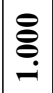 & $\stackrel{\mathcal{f}}{\stackrel{0}{0}}$ & $\begin{array}{l}\infty \\
\stackrel{\infty}{0} \\
0\end{array}$ & : & $\stackrel{\overbrace{}}{\stackrel{0}{0}}$ \\
\hline & $\begin{array}{l}0 \\
0 \\
0 \\
i\end{array}$ & $\left|\begin{array}{l}\mid c \\
0 \\
0 \\
i\end{array}\right|$ & $\frac{2}{\circ}$ & :े & $\begin{array}{l}\text { ते } \\
\text { ते }\end{array}$ & 今ે & $\stackrel{0}{=}$ & 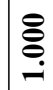 & $\begin{array}{l}\stackrel{\partial}{\partial} \\
\dot{0}\end{array}$ & $\begin{array}{l}n \\
0 \\
0\end{array}$ & $\begin{array}{l}\text { ते } \\
\text { ते }\end{array}$ & $\mid \begin{array}{l}\infty \\
0 \\
0 \\
0\end{array}$ & $\frac{\text { సे }}{0}$ \\
\hline & $\mid \begin{array}{l}\hat{a} \\
0 \\
0 \\
i\end{array}$ & $\begin{array}{l}\tilde{a} \\
\vdots \\
\dot{0}\end{array}$ & 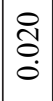 & $\bar{\sigma}$ & $\begin{array}{l}\hat{o} \\
\hat{o} \\
\dot{0}\end{array}$ & $\stackrel{\ominus}{\rightrightarrows}$ & ڤ્犬 & $\stackrel{\varrho}{\rightleftharpoons}$ & $\mid \begin{array}{l}\text { Ia } \\
\vdots \\
\vdots \\
i\end{array}$ & \begin{tabular}{l}
$\alpha$ \\
$\stackrel{\infty}{0}$ \\
\hdashline
\end{tabular} & $\stackrel{a}{0}$ & $\begin{array}{l}\text { à } \\
\text { o. }\end{array}$ & $\begin{array}{l}\text { ठิ } \\
\text { i. }\end{array}$ \\
\hline & $\mid \begin{array}{l}0 \\
0 \\
0 \\
0\end{array}$ & $\mid \begin{array}{c}0 \\
0 \\
0\end{array}$ & $\stackrel{\vec{I}}{0}$ & $\begin{array}{l}\text { ñ } \\
\text { ñ } \\
i\end{array}$ & 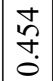 & 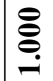 & $\stackrel{\circ}{\exists}$ & ڤ్̀ & $\begin{array}{l}\hat{\sigma} \\
0 \\
0\end{array}$ & $\begin{array}{c}\tilde{2} \\
\tilde{\sigma}\end{array}$ & 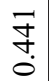 & $\frac{0}{0}$ & 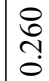 \\
\hline & D. & $\begin{array}{l}\mathfrak{Z} \\
0\end{array}$ & ¿্. & స్ & ప్ & $\begin{array}{l}\text { ta } \\
\text { and } \\
0\end{array}$ & ô. & 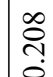 & $\stackrel{\circ}{\circ}$ & $\frac{8}{0}$ & fy & $\begin{array}{l}+ \pm \\
\stackrel{+}{*} \\
\stackrel{0}{0}\end{array}$ & $\stackrel{6}{6}$ \\
\hline & $\check{n}$ & t & $\tilde{\Xi}$ & 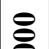 & $\overline{0}$ & $\approx$ & $\Xi$ & 8 & $\stackrel{\infty}{\sim}$ & $\stackrel{0}{=}$ & ల & to & $\stackrel{\sim}{~}$ \\
\hline & 0 & i & 0 & $\ddot{ت}$ & $\tilde{\sigma}$ & i & 0 & 0 & i & $\dot{i}$ & i & i & $\stackrel{i}{i}$ \\
\hline & $\begin{array}{l}\infty \\
0 \\
0 \\
0\end{array}$ & 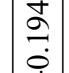 & : & $\underset{\delta}{\tilde{\delta}}$ & \& & $\bar{\Xi}$ & ¿্రి & 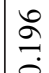 & 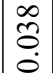 & $\stackrel{ \pm}{=}$ & $\stackrel{m}{b}$ & $\hat{\tilde{o}}$ & $\overline{\mathrm{\delta}}$ \\
\hline & & & J & t & $\simeq$ & $\infty$ & I & $\delta$ & t) & \& & $\bar{\sigma}$ & 8 & $=$ \\
\hline & 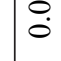 & & $\overrightarrow{8}$ & in & $1-$ & 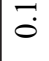 & : & 1 & : & O. & . & : & : \\
\hline & ఏ్ & $\begin{array}{l}\tilde{J} \\
0 \\
0 \\
0\end{array}$ & $\begin{array}{l}\infty \\
0 \\
0 \\
0\end{array}$ & है & 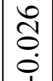 & $\begin{array}{l}t \\
\text { Oे } \\
0\end{array}$ & 롱 & ô & 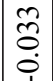 & $\begin{array}{l}\Xi \\
\vdots \\
0\end{array}$ & $\begin{array}{l}\partial \\
\dot{\partial} \\
\dot{i}\end{array}$ & : & : \\
\hline & & $\frac{x}{x=1}$ & 2 & 당 & $\hat{\bar{z}}$ & 된 & है & $U_{\Sigma}^{U}$ & $\hat{\mathbf{z}}$ & $\underline{\underline{z}}$ & $\underline{\underline{z}}$ & 된 & $\sum_{z}$ \\
\hline
\end{tabular}

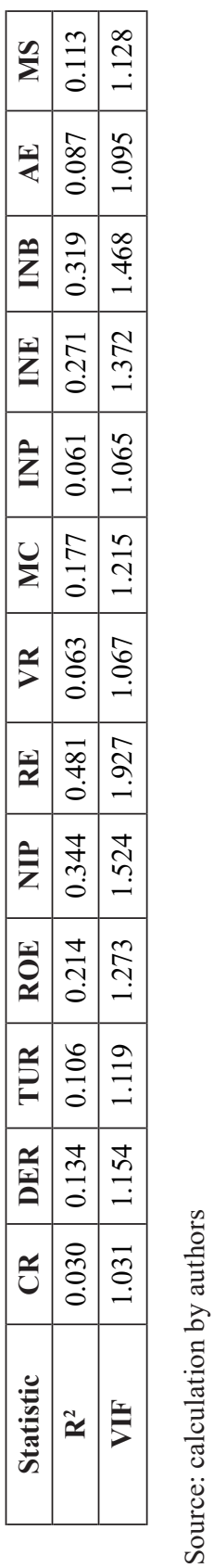


Table 9: Correlation matrixes

\begin{tabular}{|c|c|c|}
\hline Variables & RI & CR \\
\hline RI & 1 & 0.003 \\
\hline CR & 0.003 & 1 \\
\hline
\end{tabular}

\begin{tabular}{|c|c|c|}
\hline Variables & RI & DER \\
\hline RI & 1 & 0.064 \\
\hline DER & 0.064 & 1 \\
\hline
\end{tabular}

\begin{tabular}{|c|c|c|}
\hline Variables & RI & TUR \\
\hline RI & 1 & 0.026 \\
\hline TUR & 0.026 & 1 \\
\hline
\end{tabular}

\begin{tabular}{|c|c|c|}
\hline Variables & RI & ROE \\
\hline RI & 1 & 0.322 \\
\hline ROE & 0.322 & 1 \\
\hline
\end{tabular}

\begin{tabular}{|c|c|c|}
\hline Variables & RI & NIP \\
\hline RI & 1 & 0.790 \\
\hline NIP & 0.790 & 1 \\
\hline
\end{tabular}

\begin{tabular}{|c|c|c|}
\hline Variables & RI & RE \\
\hline RI & 1 & 0.404 \\
\hline RE & 0.404 & 1 \\
\hline
\end{tabular}

\begin{tabular}{|c|c|c|}
\hline Variables & RI & VR \\
\hline RI & 1 & 0.169 \\
\hline VR & 0.169 & 1 \\
\hline
\end{tabular}

\begin{tabular}{|c|c|c|}
\hline Variables & RI & MC \\
\hline RI & 1 & 0.292 \\
\hline MC & 0.292 & 1 \\
\hline
\end{tabular}

\begin{tabular}{|c|c|c|}
\hline Variables & RI & INP \\
\hline RI & 1 & 0.056 \\
\hline INP & 0.056 & 1 \\
\hline
\end{tabular}

\begin{tabular}{|c|c|c|}
\hline Variables & RI & INE \\
\hline RI & 1 & 0.170 \\
\hline INE & 0.170 & 1 \\
\hline
\end{tabular}

\begin{tabular}{|c|c|c|}
\hline Variables & RI & INB \\
\hline RI & 1 & 0.344 \\
\hline INB & 0.344 & 1 \\
\hline
\end{tabular}

\begin{tabular}{|c|c|c|}
\hline Variables & RI & AE \\
\hline $\mathrm{RI}$ & 1 & 0.074 \\
\hline $\mathrm{AE}$ & 0.074 & 1 \\
\hline
\end{tabular}

\begin{tabular}{|c|c|c|}
\hline Variables & RI & MS \\
\hline RI & 1 & 0.128 \\
\hline MS & 0.128 & 1 \\
\hline
\end{tabular}

Source: calculation by authors 
Table 10: The test statistic of significant correlation

\begin{tabular}{|c|c|c|c|c|}
\hline Variable & T (test statistic) & $\mathbf{T}_{\text {crit }}$ (critical value) & p-value (two-tailed) & alpha \\
\hline CR & 0.054995 & 1.965013 & 0.956 & 0.05 \\
\hline DER & 1.396096 & 1.965013 & 0.566 & 0.05 \\
\hline TUR & 0.57502 & 1.965013 & $<0.0001$ & 0.05 \\
\hline ROE & 7.387359 & 1.965013 & $<0.0001$ & 0.05 \\
\hline NIP & 27.93862 & 1.965013 & $<0.0001$ & 0.05 \\
\hline RE & 9.585949 & 1.965013 & $<0.0001$ & 0.05 \\
\hline VR & 3.725166 & 1.965013 & $<0.0001$ & 0.05 \\
\hline MC & 6.617913 & 1.965013 & 0.222 & 0.05 \\
\hline SC & 1.223255 & 1.965013 & $<0.0001$ & 0.05 \\
\hline INP & 3.732676 & 1.965013 & $<0.0001$ & 0.05 \\
\hline INE & 7.947842 & 1.965013 & 0.107 & 0.05 \\
\hline INB & 1.616102 & 1.965013 & $<0.0001$ & 0.05 \\
\hline AE & 2.811178 & 1.965013 & & \\
\hline
\end{tabular}

Source: calculation by authors 